\title{
What drives smallholder farmers' crop production choices in Central Zambia? Lessons from the 2012/2013 agricultural season
}

\author{
Kabwe Harnadih Mubanga (Corresponding author) \\ Department of Geography, Centre for Environmental Studies \\ University of Pretoria, Pretoria, South Africa
}

Tel: 278-2633-3602 E-mail: kabwe.mubanga@live.com

\section{Bridget Bwalya Umar}

Department of Geography and Economic History, Umea University, Umea, Sweden Email: brigt2001@yahoo.co.uk; brbwalya@unza.zm

\begin{abstract}
Jane Muchabi
Ministry of Agriculture and Livestock, Department of Agriculture, Shibuyunji, Zambia Email: jmuchabi@gmail.com
\end{abstract}

\begin{abstract}
Chishimba Mubanga
Ministry of Agriculture and Livestock, Department of Agriculture, Shibuyunji, Zambia Email: chishimbamubanga@yahoo.com
\end{abstract}

Received: February 20, 2015 Accepted: March 5, 2015

doi:10.5296/jas.v3i2.7125 URL: http://dx.doi.org/10.5296/jas.v3i2.7125

\begin{abstract}
The study, conducted in central Zambia was aimed at determining the major drivers of crop production choices among smallholder farmers. It utilized recent national crop production and utilization data; 200 semi-structured interview schedules, and key informant interviews
\end{abstract}


conducted with smallholder farmers and experts from the agricultural sector in Zambia respectively. Results showed that despite being confronted by late on-set of rains and post germination crop attacks by army worms which made maize (Zea mays) production extremely precarious, $61.5 \%$ of the affected smallholder farmers replanted their cultivated land with maize. The farmers had a choice of whether to replant maize which had a ready market from the state agency, the Food Reserve Agency, or to plant a drought tolerant crop such as sorghum or millet which would have guaranteed them with household food security from own production. They mainly chose the former option. They increased production of other crops such as soya beans (Glycine max), sun flower (Helianthus annuus) and cotton (Gossypium hirsutum) when contract farming with private business entities became available. Markets determined smallholder farmers' crop production choices more than household food security from own production or availability of climate information forecasting poor rainfall distribution. The study concludes that (i) prior knowledge of climate information does not necessarily result in a change of smallholder farmers' crop production choices in response to a predicted climate anomaly, (ii) markets are a major determinant of crops cultivated by smallholder farmers, and hence adaptation measures involving crop diversification should be designed with market availability in mind.

Keywords: Climate information; conservation agriculture; food security; maize; markets

\section{Introduction}

Smallholder farmers in Zambia as in the rest of Sub Saharan Africa (SSA) face many challenges which contribute to their household food insecurity. For farmers in semi-arid areas of the region, major risks to agriculture involve water stress as a result of erratic, and insufficient or poorly distributed rainfall (Rosegrant et al., 2002). Agriculture for many of these farmers is rain-fed; hence they face a high risk of household food insecurity resulting from climate change and variability. While smallholder farmers might apply different methods to deal with climatic shocks and other risks, such as suitable crop and variety choice, application of fertilizer, planting density, and water harvesting (Aune and Bationo, 2008), they still contend with household food insecurity as their challenges involve a lot more than just extreme climatic events. For these smallholder farmers, it is not only floods or extreme droughts that are important to their sustainability. Such phenomena as intra-seasonal variability (Thomas et.al. 2007), the time at which the effective planting rains come, distribution of rainfall throughout the farming season (Mortimore and Adams, 2001), and how effective rainfall events are during each precipitation event (Usman and Reason, 2004), are more critical as they determine the yields for a particular season.

Adaptations in agricultural practices of smallholder farmers has been advanced in both popular and scientific literature as a major vehicle to achieving food security (Armitage et al., 2008; Câmpeanu and Fazey, 2014; Ericksen and Ingram, 2005; Gohari, 2013; Mubanga and Umar, 2014). To this end, the need for accurate climate information and efficient early warning might be seen as a means of ensuring smooth and effective farmer adaptation. Information about rainfall intensity and distribution within a particular season has been propagated as a major driver in changing farming methods or farming practices of smallholder farmers in rain fed 
systems (Mortimore and Adams, 2001; Vogel, 2000). The reactive adaptation measures expected to follow in cases of unfavourable climate information provision include; change in tillage practices, change in seed variety to be used or even change in crops cultivated by the affected farmers (Klein, 2003). These changes are all anticipated as efforts by smallholder farmers to ensure household food security and are expected to come about as a result of either farmer's access to seasonal rainfall forecasts or as a reactive adaptation measure to crop stresses observed early in the growing season. The crop stress might result from intra-seasonal droughts or floods to invading pests.

Although climatic factors influence the yields realized from a crop planted, they are not the only factors that dictate crop production choices and ultimately the household food security status of smallholder farming households. Crop production choices may also be influenced by farming households' desire to secure consumption from own production, market failures, and roles of state and non-state actors (Umar, 2011; 2013). This implies that although a well-chosen crop type with soil and climatic characteristics suitable for a particular region is more likely to produce higher yields as compared to a randomly chosen one, this in itself is not a sufficient reason for farming households to plant that crop. Other factors, which could be economic, socio-cultural or institutional, and equally likely to impinge on the household's food security status, may be at play. The factors and their salience, in influencing crop production choices vary across local, regional and national boundaries.

Understanding which factors influence smallholder farming households' crop choices is important as it can inform agricultural development interventions. Such information is important for development actors as they make decisions on the design and allocation of scarce resources to agricultural interventions that are more likely to have positive effects as they will be in line with the motivations of their targeted beneficiaries, smallholder farming households. This study, conducted in Shibuyunji district of central Zambia, was aimed at determining the drivers of crop choices by smallholder farmers in light of the available climate and local agriculture information during the 2012/2013 agricultural season. The purpose was to establish the major drivers of smallholder farmers' choice of crops cultivated in the district and derive some lessons for actors in the agriculture sector. The study finds that markets were the most important determinant of smallholder farmer crop choices as farmers dedicated disproportionate areas of land to the cultivation of crops whose market was guaranteed either by the state or by private firms.

\section{Description of Study Area}

Shibuyunji district is located in central Zambia about $70 \mathrm{~km}$ west of the capital city, Lusaka (Figure 1). It covers an estimated total area of $2087 \mathrm{~km}^{2}$ and lies between latitudes $15^{\circ} 20^{\prime} 0^{\prime \prime}$ south of the equator and longitude $27^{\circ} 56^{\prime} 0^{\prime \prime}$ east. It receives average rainfall of between $800 \mathrm{~mm}-1000 \mathrm{~mm}$ which has a uni-modal seasonal distribution. The crop growing season ranges from 100 to 140 days (Saasa, 2003). 


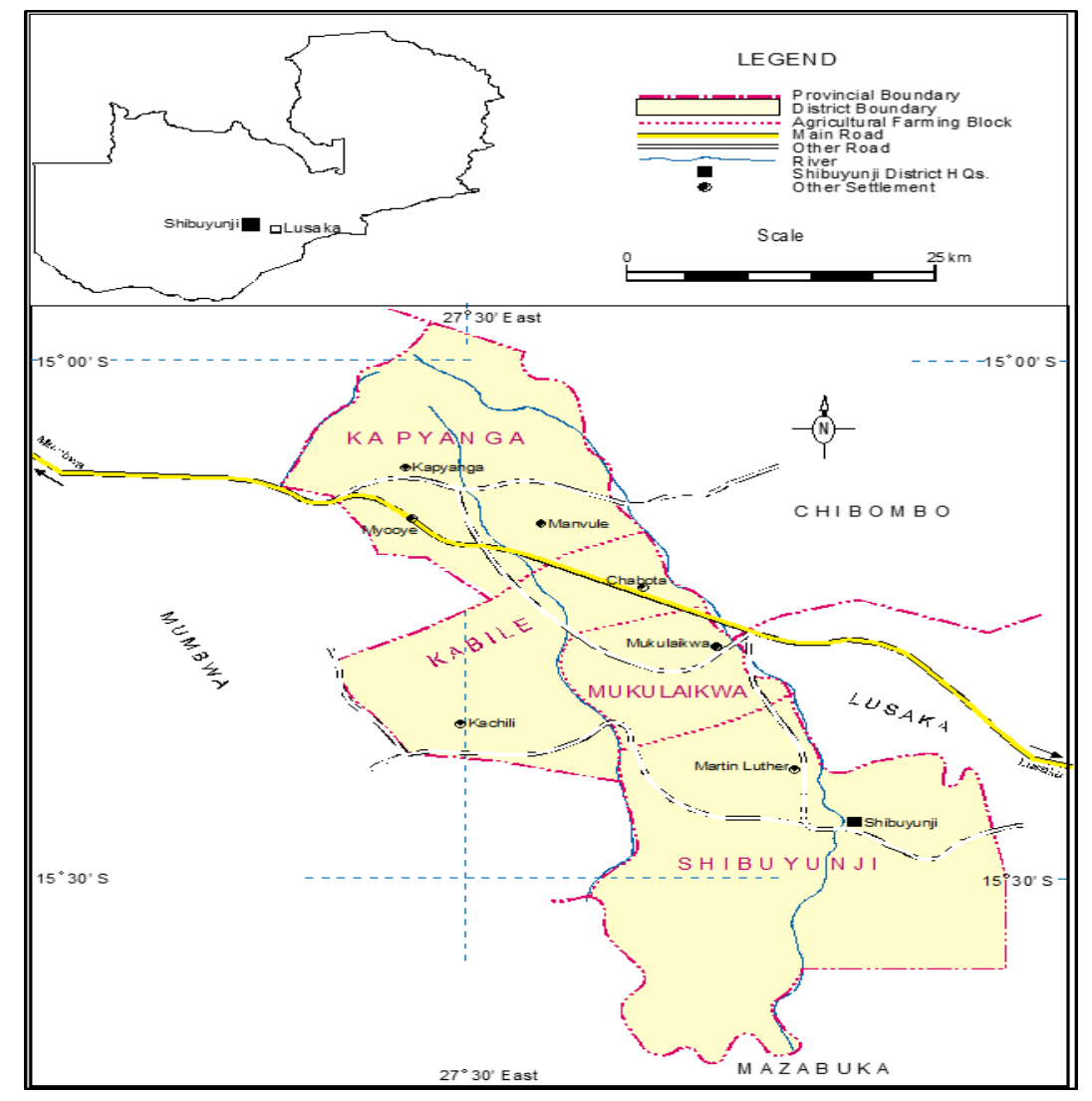

Figure 1. Shibuyunji District, Zambia

\subsection{Rainfall Characteristics of the Study Area}

The rainfall events in the area run from October to March with occasional rains in April. In the 2012/2013 season, Shibuyunji District started receiving rainfall in October. However, the effective planting rainfall was only received in the second week of December. This was the first opportunity for planting of most of the rain-fed crops and farmers took advantage of the opportunity. Ideally, planting ought to happen between 15th and 30th November (CFU, 2007) but the intra-seasonal drought experienced early in the season precluded any planting prior to mid-December. Most of the maize fields were attacked by an outbreak of army worms (Pseudaletia unipuncta) soon after germination. The affected farmers replanted their maize soon after the army worm infestation cleared. Consequently maize planting in the district continued up to late January.

Seasonal rainfall was below normal in magnitude and was poorly and differentially distributed in time and space among the districts' three agricultural blocks (Table 1). In the Zambian agricultural sector administration system, each district is subdivided into agricultural blocks, which are further divided into agricultural camps. A camp is the lowest level of agricultural administration and is ideally supposed to cover a radius of $15 \mathrm{~km}$. Shibuyunji district has three agricultural blocks. 
Table 1. Rainfall and temperature information for Shibuyunji district for 2012/2013 agricultural season

\begin{tabular}{|l|l|l|}
\hline Agricultural Blocks in Shibuyunji & Average Rainfall $(\mathrm{mm})$ & \multirow{2}{*}{ Mean Temperature $\left({ }^{\circ} \mathrm{C}\right)$} \\
\hline Shibuyunji & 812 & \multirow{2}{*}{$21.5^{\circ} \mathrm{C}\left(17-26^{\circ} \mathrm{C}\right)$} \\
\cline { 1 - 2 } Mukulaikwa & $507^{*}$ & \multicolumn{1}{|}{} \\
\cline { 1 - 2 } Kapyanga & $489^{*}$ & \\
\hline
\end{tabular}

The information covers the period from November 2012 to March 2013.

*Below average rainfall.

\subsection{Population Characteristics of the Study Area}

Shibuyunji district has an estimated total population of 49551 and 9764 households (CSO, 2011). Its population density of 24 persons per $\mathrm{km}^{2}$ is higher than the national average of 17 . It is an agricultural district with livestock rearing and crop production being the main activities. During the 2012/2013 agricultural season, 40480 hectares of land was under cultivation while cattle population was at 32030 (Ministry of Agriculture and Livestock, 2014: 6). The common types of livestock reared are cattle, goats, pigs, and a few donkeys while poultry consists mainly of free ranging chickens, guinea fowls and ducks. Livestock are important especially in times of hunger when through distress sales, most livestock owning households are able to purchase food (Tembo et al., 2014).

Shibuyunji District was created in 2011 and was hitherto a constituency under Mumbwa District in central Zambia. It was one of the districts severely hit by an army worm outbreak during the 2012/2013 agriculture season and hence provided a good case to study the behavior of smallholder farmers towards their crop production choices in light of the climatic and pest hurdles experienced.

\section{Methods}

Data for this study was collected during the 2012/ 2013 agricultural season over the period October 2012 to September 2013. The period covered a full crop growing cycle from land preparation, seed planting, weeding, to crop harvesting and marketing. The data was collected during two routine annual surveys conducted by the Ministry of Agriculture and Livestock (MAL), in collaboration with the Central Statistical Office. These two surveys are known as the Crop Forecast and Post-Harvest Surveys respectively. The crop forecast survey which has a national sample size of 13600 agricultural households per year provides statistically representative estimates of crop production, area and yield at the national, provincial, and district levels from both smallholders and commercial farmers. The survey is conducted prior to crop harvest and records anticipated production and yield estimates based on the expert judgment of farmers. While it is understood that crop damage can occur after the survey is conducted, most crops in the country have already reached physiological maturity when the survey is conducted (IAPRI, 2014). The post-harvest survey is conducted in the same areas that are covered for the crop focus survey. The crop forecast data used in this study was collected between December 2012 and January 2013 while the post-harvest survey followed from July to 
November 2013. The data pertaining to Shibuyunji district was extracted from the national datasets for both surveys.

Information on drivers of smallholder farmers' crop choices was obtained through a routine survey by MAL using a questionnaire administered to selected respondents who were purposively sampled on the basis of their having been farmers for a minimum of 5 years. A total of 200 farmers gave back their responses. Key informant interviews with officials from MAL as well as traditional leaders also formed part of the data collection package. A review of government agriculture reports related to provision of inputs, legislation, strategic plans beside literature on smallholder crop production was conducted in order to enhance the researchers' understanding of smallholder agriculture.

Analyses of the collected data were done using both qualitative and quantitative techniques. Quantitative analyses utilized statistical analyses software SPSS 22 and Microsoft Excel 10. Descriptive statistics including percentages, means, and graphs were derived using these software and formed tools for quantitative analysis. Qualitative data analysis was done using thematic analysis technique in which the responses were isolated into key emerging themes (Langdridge, 2004).

\section{Results}

Two of the three agricultural blocks in Shibuyunji district (Mukulaikwa and Kapyanga) had below expected rainfall while the other (Shibuyunji) recorded marginally normal rainfall during the 2012/2013 agricultural season. This was particularly worrisome for maize farmers most of whom planted the medium maturing hybrid maize varieties which required at least $800 \mathrm{~mm}$ of well distributed rainfall. To compound the situation, army worms invaded maize fields soon after germination and farmers replanted their maize up to as late as January, 2013. The challenges to crop choices faced by the smallholder farmers in the district were compounded by the situation they found themselves in of planting maize in January considering the varieties available for planting required a growing period of 100-140 days while only 90 days of rainfall remained till the end of the season. Notwithstanding the challenges already highlighted, maize is naturally a sensitive crop and changes in weather conditions or intra-seasonal droughts occurring during seasons of high or low rainfall, can result in high yield loss particularly if the changes occur during germination or flowering (FAO, 2011; Umar and Nyanga, 2011). During the period under study both the amounts and distribution of rainfall for Shibuyunji were unsatisfactory for the optimum production of maize. This increased the precariousness of rain-fed maize agriculture.

\subsection{Area under Cultivation for Major Crops in the 2012/2013 Agriculture Season}

Farmers reserved $65 \%$ of their total cultivated land towards the growing of maize despite the seeming odds against a good maize harvest in the 2012/2013 growing season (Figure 2). The other crops cultivated included sunflower (Helianthus annuus), cotton (Gossypium hirsutum), groundnuts (Arachis hypogaea), cassava (Manihot esculenta) and soya beans(Glycine max). 

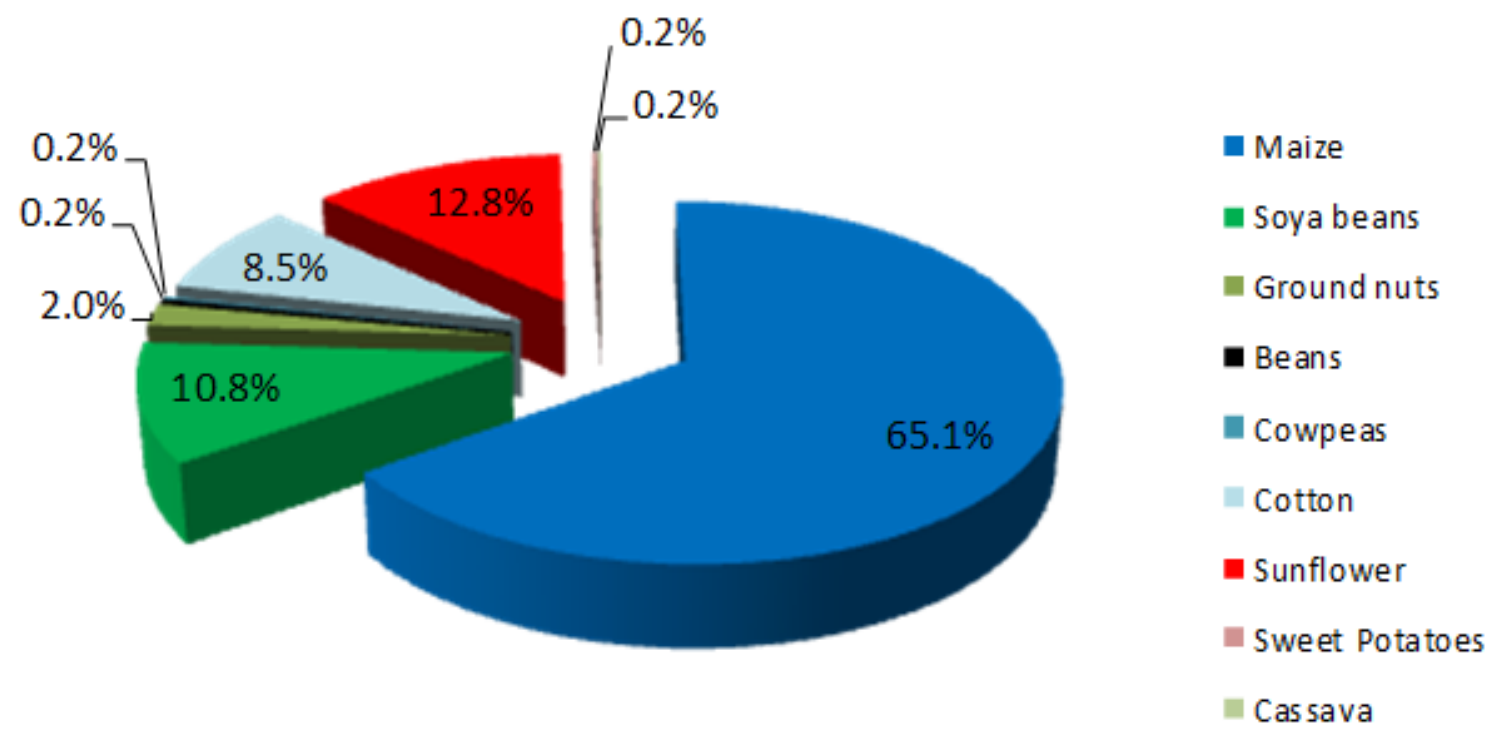

Figure 2. Area allocated towards cultivation of major crops in Shibuyunji district during the 2012/2013 agricultural season.

The relative importance of each of these crops to the farmers could be seen from the proportion of land they allocated to their cultivation (Figure 2). The dominance of maize production in Shibuyunji is clear but not unique. An aerial survey conducted in the southern province of the country in 1992 revealed that only $2 \%$ of smallholder lands were utilized for crops other than maize (Saasa, 2003:13). Commentators on Zambia's historical and current agricultural sector development have observed the sectors pre-occupation with maize production (Farringston and Saasa, 2002; Haggblade and Tembo, 2003; Sitko, 2011; Zulu et al., 2000). The dominance of maize production among smallholder farmers is attributable to several related factors. Since the country's independence in 1964, government agricultural policy has mainly focused on the provision of incentives for maize production and marketing (Tembo and Jayne, 2010).

The Farmer Input Support Programme (FISP) is a nationwide government subsidy programme through which smallholder farmers receive subsidized mineral fertilizer and free seed (Figure 3). Beneficiary farmers receive one pack of inputs which is sufficient for planting half (0.5) a hectare of land. Criteria for a smallholder farmer to benefit from FISP are that the farmer has to be a member of a registered farmer cooperative and should be cultivating between 1 and 5 hectares of land. The distribution of inputs was such that each beneficially farmer had a choice of their preferred input pack. During the period under review, a total of 7466 smallholder farmers benefited from FISP with 7180, 236 and 50 receiving maize, cotton and groundnut packs, respectively. The 7466 farmers represented $50 \%$ of the registered farmers in the district. The maize packs were selected by most farmers, showing the dominance of maize cultivation in the district.

Upon harvest, smallholder farmers have the opportunity to sell their maize to a government agency, the Food Reserve Agency (FRA) at floor prices that are announced at the beginning of 
the marketing season. The maize floor price is pan-territorial and pan-seasonal making it possible for smallholder maize producers in areas far from good roads and other communications infrastructure to be able to sell their maize at the same price as their counterparts in areas with more developed markets.

\section{Typology of Input Subsidy Packages}

i) $\rightarrow$ Maize pack: $2 \times 50 \mathrm{~kg}$ basal dressing fertilizer, $2 \times 50 \mathrm{~kg}$ top dressing fertilizers and $1 \times 10 \mathrm{~kg}$ bag Maize seed

ii) $\rightarrow$ Sorghum pack: $2 \times 50 \mathrm{~kg}$ basal dressing fertilizer, $1 \times 50 \mathrm{~kg}$ top dressing fertilizer and $1 \times 5 \mathrm{~kg}$ sorghum seed

iii) $\rightarrow$ Rice pack: $1 \times 50 \mathrm{~kg}$ basal dressing fertilizer, $1 \times 50 \mathrm{~kg}$ top dressing fertilizer and $1 \times 10 \mathrm{~kg}$ bag rice seed

iv) $\rightarrow$ Groundnuts pack: $1 \times 50 \mathrm{~kg}$ bag basal dressing fertilizer, $1 \cdot \times 20 \mathrm{~kg} \cdot \mathrm{bag}$ groundnuts

v) $\rightarrow$ Cotton pack: $2 \times 50 \mathrm{~kg}$ basal dressing fertilizer, $1 \times 10 \mathrm{~kg}$ cotton seed

Figure 3. Typology of input subsidy packages under the Fertilizer Input Support Programme.

Basal fertilizer is $\left(\mathrm{N}: \mathrm{P}_{2} \mathrm{O}: \mathrm{K}^{2} 0,10: 20: 10\right)$ while top dressing fertilizer is $46 \% \mathrm{~N}$.

Additionally, FRA sets up points at which farmers can deliver their maize to its agents in their locality. This is equivalent to a transport subsidy as these maize producers do not have to travel long distances to sell their maize. Analyses of the government set floor prices have revealed that these prices have been above market price levels (Mason and Myers, 2011) and have in effect encouraged hybrid maize adoption (Hamazakaza et al., 2013) and allocation of more land to maize and less to other crops (Umar, 2012). As of 2011/2012 agricultural season, over 1.2 million hectares of smallholder land was dedicated to maize production. This represents approximately 66 percent of the total smallholder land under cultivation in Zambia (Chamberlain et al., 2014: 1).

Also notable from Figure 2 is that farmers in Shibuyunji did not grow any cereal crops which could act as substitutes for maize, the staple crop in Zambia while the root crops, cassava and sweet potatoes (Ipomoea batatas) collectively contributed less than $1 \%$ of the total cultivated area. The low quantities could be explained by their low tradability as they are easily perishable crops.

Noteworthy from Figure 2 are the relatively high proportions of land allocated for sunflower, soya beans and cotton production. During the 2012/2013 agricultural season these crops also had a ready market from cooking oil manufacturing companies and cotton ginneries located within the area as they were under crop grower schemes. Despite their being perceived as unpopular, farmers in Shibuyunji area apportioned relatively large proportions of their land to the cultivation of sunflower, soya beans and cotton with a total of 4499, 3805, and 2978 hectares allocated to sunflower, soya beans and cotton respectively. This development was due to the existence of a ready market during the 2012/2013 agriculture season. This is explained in more detail in the next section. 


\subsection{Crops Produced Versus Crops Sold}

By definition, smallholder farmers are partially engaged in input and output markets and are both producers and consumers (Ellis, 1993). They depend for their livelihoods on the production of food and other products that are provided by their own farms (Abebe, 2013). For crops such as maize, groundnuts, beans, and sweet potatoes, the farmers only sold part of the produce and retained the rest for household consumption while for crops such as soya beans, sunflower, and cotton, almost all the produce was sold (Table 2).

Cotton was produced under contract farming with cotton companies which provided inputs and extension services to the farmers (Chapoto et al., 2012). Three cotton companies-Dunavant, Alliance Ginneries, and Cargill- have a presence in the area. The farmers were legally obliged to sell the cotton to the cotton company that has provided the input loan at prices determined by the company after harvest. The farmers did not have to risk their own inputs for cotton production (Ibid). This seems to have positively influenced farmers' choices to grow cotton (Govereh et al., 2008).

Farmers also made the choice to grow crops traditionally considered unpopular in Shibuyunji due to incentives provided by oil and food processing companies; and Non- Governmental Organizations (NGOs). Unified Chemicals Zambia Ltd and Zambeef Products Plc. encouraged soya bean and sunflower production through contract farming arrangements which ensured ready markets for the two crops that smallholder farmers usually only produce under guaranteed market conditions.

Table 2. Crop production and sales in Shibuyunji District, 2012/2013 agricultural season

\begin{tabular}{|c|c|c|c|}
\hline Crop & Quantity Produced (MT) & Quantity Sold (MT) & Percentage of crops sold \\
\hline Maize & 410.71 & 142.83 & 34.78 \\
\hline Soya beans & 4.74 & 4.52 & 95.32 \\
\hline Ground nuts & 0.60 & 0.38 & 63.94 \\
\hline Beans & 0.06 & 0.03 & 54.94 \\
\hline Cowpeas & 0.64 & 0.05 & 8.48 \\
\hline Cotton & 2.03 & 1.95 & 96.15 \\
\hline Sunflower & 2.88 & 2.86 & 99.20 \\
\hline Sweet Potatoes & 0.40 & 0.22 & 54.88 \\
\hline Cassava & 0.43 & 0.12 & 27.82 \\
\hline
\end{tabular}

MT = metric tonnes. $1 \mathrm{MT}=1000$ Kilograms.

Concern Zambia and The International Institute of Tropical Agriculture (IITA) are two international NGOs operating in the study area on projects specifically aimed at encouraging crop diversification through the production of so called minor crops (Table 3). Through its RAIN (Realigning Agriculture to Improve Nutrition) Project, Concern Zambia has promoted legume production not only for protein provision to households but also for soil nitrogen fixation. IITAs MIRACLE (Making Agricultural Innovations Work for Smallholder Farmers Affected by HIV/AIDS in Southern Africa) project interventions include the production, consumption, and marketing of nutritious crop and livestock products. In Shibuyunji, the 
MIRACLE project interventions included the promotion of legume production by giving out input packages to selected farmers who the project also trained in best agronomic practices for legume production. The input packages included cowpeas, soya beans and groundnuts. Up to 700 smallholder farming households were supported in this way.

Table 3. Organizations supporting smallholder arable agriculture in Shibuyunji district

\begin{tabular}{|c|c|c|}
\hline No. & Name of organization & Activities involved in \\
\hline 1. & Harvest Plus & $\begin{array}{l}\text { Promoting cultivation of vitamin A fortified maize, sweet } \\
\text { potatoes, and groundnuts. }\end{array}$ \\
\hline 2 & $\begin{array}{l}\text { Dunavant/ Cargill/ Alliance } \\
\text { Ginneries }\end{array}$ & Cotton production \\
\hline 3. & $\mathrm{CFU}$ & Conservation agriculture \\
\hline 4. & IITA (MIRACLE Project) & $\begin{array}{l}\text { Promoting legume production e.g. soya beans, cow peas, } \\
\text { groundnuts. }\end{array}$ \\
\hline 5. & Concern Zambia (RAIN Project) & $\begin{array}{l}\text { Promoting crop diversification to unpopular crops e.g. soya } \\
\text { beans and sugar beans }\end{array}$ \\
\hline 6. & $\begin{array}{l}\text { Unified Chemicals Zambia/ Zambeef } \\
\text { Products }\end{array}$ & $\begin{array}{l}\text { Promoting growing of crops used for oil production e.g. soya } \\
\text { beans and sunflower }\end{array}$ \\
\hline
\end{tabular}

The Conservation Farming Unit (CFU), a unit under the Zambia National Farmers Union has been promoting conservation agriculture in the area. One of the principles of conservation agriculture encouraged by $\mathrm{CFU}$ in the area is crop rotation using leguminous crops such as soya beans, velvet beans (Mucuna pruriens), and groundnuts. CFU encourages its farmers by inter alia, providing them with free legumes seeds. Following the introduction of conservation agriculture activities in the area during the 2009/2010 agricultural season, the district recorded an increase in production and productivity of crops with maize moving from an average yield of 2 tonnes to 2.2 tonnes per hectare for non-CA and 3.5 tonnes per hectare for CA smallholder farmers respectively (Department of Agriculture Official, personal communication.).

Other than maize; soya beans, cotton and sunflower were the only other crops to have over 1 MT produced during the 2012/2013 agricultural season. The rest of the crops-with no guaranteed market-were only cultivated in trace amounts as they were considered mainly as crops for household consumption only. For example, less than $10 \%$ of the cowpeas produced were sold. This highlights the important role that activities of private business entities and NGOs play in influencing smallholder farming households' crop choices.

\subsection{Vegetable Production}

Smallholder vegetable production is engaged in during the dry season on fields close to perennial water bodies such as small rivers and streams. Small scale irrigation systems are employed. Vegetable production is thus the preserve of those smallholder farming households that have fields close to perennial water sources. During the 2012/ 2013 agricultural season, farmers in Shibuyunji allocated 54 hectares of land for vegetable production. The vegetables cultivated included rape (Brassica napus), onion (Allium cepa), Kalembula (leaves of Ipomoea 
batatas), African eggplant (Solanumt orvum), okra (Abelmoschus esculentus) and tomatoes (Solanum lycopersicum).

Table 4. Off-season vegetable crop production in Shibuyunji district, 2012/2013 agricultural season

\begin{tabular}{|c|c|c|c|}
\hline Vegetable & Area planted (ha) & Quantity produced (MT) & No. of households engaged in production \\
\hline Rape & 2.5 & 17 & 48 \\
\hline Onion & 1.5 & 0.23 & 39 \\
\hline Kalembula & 8.0 & 172.5 & 42 \\
\hline African eggplant & 15 & 100.8 & 109 \\
\hline Okra & 24 & 100 & 69 \\
\hline Tomatoes & 15 & 180 & 13 \\
\hline Total & 54 & & \\
\hline
\end{tabular}

Most of the vegetables were transported to Lusaka for sale and formed the main source of income for farmers during the maize off-season. Vegetables are the second highest earner of smallholder farmers' income in the district after maize (Department of Agriculture Official personal communication).

\subsection{Drivers of Smallholder Farmers' Crop Choices- Their Views}

The results from the 200 farmers interviewed showed availability of markets as the most widely cited driver for their crop production choice (Table 5). In fact even household food security ranked second behind markets as a driver for smallholder farmers' choice of crop production. Climate information was ranked fourth. The low importance attached to climate information is contrary to results reported by Arimi (2014) who found that among smallholder farmers in Nigeria, access to early warning information was a major predictor of adaptation.

Table 4. Reasons for smallholder farmers' choice of crops for production

\begin{tabular}{|l|l|}
\hline Reasons for cultivation of particular crops & Percentage of Farmers $(\%) \mathrm{n}=200$ \\
\hline Availability of markets & 100 \\
\hline Household food security & 94 \\
\hline Availability of inputs & 72 \\
\hline Does well under current weather & 32 \\
\hline Less labour intensive & 16 \\
\hline
\end{tabular}

The findings in Table 5 agree with the conclusions from the analysis of the crop production data. Maize not only had guaranteed markets, but was important for household consumption and the availability of maize seed and fertilizer was enhanced through FISP. Soya beans, cotton and sunflower were cultivated more due to the markets and inputs provided by interested non state actors. The more the availability of markets, the higher the quantities of a crop produced. Smallholder farmers allocated most of their cultivated land to the production of maize. The markets attached to maize cultivation were arguably the biggest incentive for the dominance of maize. During the 2012/2013 agricultural season, the government through the Food Reserve 
Agency (FRA) was buying a 50kg bag of maize for ZMW65 ( US \$10) which was higher than the prices most private buyers were offering. FRA purchased the maize from depots conveniently located close to smallholder farmers' homes for easy transportation. This reduction in transport costs highly reduced costs attached to the sale of maize thereby increasing the income derived from it. This essentially made maize production more attractive to smallholder farmers compared to other crops. The incentives for maize production arguably made the risk of crop failure worth taking by the farmers.

The government policy of buying white maize from smallholder farmers annually at above market prices has to some extent encouraged the maize mono - cropping culture and over dependency on the commodity among this group. This is because the production of other crops has not been incentivized to such high levels by the both the state and non-state actors in the agricultural sector. Private buyers and/or companies are usually the market providers for other crops and do not offer similarly high price levels and farmers have complained about what they consider to be very unattractive prices. The maize-centric agricultural policy has been inimical to other government programmes aimed at encouraging crop diversification among smallholder farmers (GRZ, 2013).

The fact that the government only bought white grade maize hindered intra- crop diversification. Currently, farmers in Shibuyunji are reluctant to engage in the production of yellow or orange maize varieties despite their nutritional superiority as these varieties are not accepted for purchase by FRA. Harvest Plus, an NGO operating in Shibuyunji has been encouraging smallholder farmers' to cultivate orange maize which is fortified with Vitamin A. However, the adoption rate has been relatively low and farmers have complained of being unable to sale it to FRA. Only small quantities are cultivated for household consumption. This reasoning has also affected production of crops more agronomically suited to the district such as sorghum, millet, cassava and sweet potatoes.

\subsection{Lessons Learnt}

Five main lessons are drawn from this study of smallholder farmers' crop choices during the 2012/2013 agricultural season in Shibuyunji. Firstly, while advance knowledge of climate information by farmers is important, mere knowledge of when and how much rainfall or rainfall distribution an area will face will not result in farmers changing their agricultural practices in response to the predicted climate anomaly. This is despite the rainfall parameter being recognized as the most important climate parameter affecting smallholder farmers yields (Vogel, 2005) under rain fed agriculture. The study showed that not even late on-set of rainfall, pest occurrence or knowledge of increased risks involved in maize production was enough to change farmers from the maize dominance culture. Such information might be useful as a starting point in sensitizing farmers on the importance of newer and more successful agricultural practices, but it will not make farmers abandon their already established practices. Secondly, the availability of markets is a major determinant of crop production choices by smallholder farmers. Farmers in the study area considered it as the most important determinant of crop choice. Knowledge of this is important as markets may emerge as a catalyst towards promoting crop diversification. Crop production is currently seen as an important adaptation 
measure to impacts of climate change (Mubanga and Umar, 2014) as well as an adaptation pathway for response to changes and stressors (Câmpeanu and Fazey, 2014). Therefore, market information should not be looked at as a separate issue from smallholder agriculture but as an integral part of it, for purposes of ensuring household food security. Enhancing food security through agro-ecological specific crop varieties should proceed from establishment of tangible markets if farmers are going to adapt to the promoted varieties. Telling farmers to grow a particular crop variety will not result in household food security if the crop they are told to cultivate does not have a ready market. Hence adaptation measures involving agro-ecological specific crops and varieties should be attached to existing markets for them to be effective. Modern technologies involving crop diversification would be more effective if crops promoted for diversification had ready markets for produce.

Thirdly, achieving household food security is not always the main objective for smallholder farmers (Swift and Hamilton, 2001). If achieving food security was the goal, farmers in the study area would have converted from maize cultivation to a more drought tolerant crop such as sorghum or millet. However, farmers preferred the assured increased incomes associated with maize production which could enable them purchase their desired materials rather than the household food security assured by a drought tolerant crop with no guaranteed income returns. Fourthly, counterproductive policies may work against the same objectives other government programmes hope to achieve. Attaching markets to maize by the government through FRA works against an established agriculture adaptive pathway in crop diversification-one of the objectives of FISP. Furthermore, crop diversification is expected to play a very important role in achieving food security as well as sustainable food systems. The fifth lesson is on the role of non-state actors in affecting farmers' crop choices such as the roles of NGOs and private business entities. The ability of these institutions to enhance crop diversification was seen in the relatively high number of hectares apportioned to promoted crops such as soya beans, sunflower and cotton compared to the non-supported crops. The growth of the agriculture sector would be accelerated through inter-institutional cooperation and this should include both promotion and marketing of produce.

\section{Conclusions}

Smallholder agriculture in Shibuyunji district was confronted by several challenges during the 2012/2013 agricultural season. The late on-set of rains and crop attacks by army worms meant conditions for re-planting of maize only became possible in late January when it was late for farmers to plant the medium maturing maize varieties available to them. The farmers had a choice of whether to plant maize which had a ready market from the state or to plant a drought tolerant crop such as sorghum or millet which would guarantee them with household food security from own production. The allocation of $65.1 \%$ of their cultivatable land to maize production with no maize substitute planted entailed that farmers opted to risk with the maize which had ready market. The study concluded that availability of markets was the major determinant of crop choice for farmers even more than availability of climate information. Several lessons were drawn from this; (i) prior knowledge of climate information will not result in a change of smallholder farmers' agricultural practices in response to the predicted climate anomaly, (ii) markets are a major determinant of particular crops cultivated by 
smallholder farmers, hence adaptation measures involving crop diversification should be designed with market information in mind, (iii) food security is not always the objective of smallholder farmers' agriculture. Knowledge of this should influence the kind of help rendered to smallholder farmers by both state and non-state actors.

\section{References}

Abebe, T. (2013). Determinants of crop diversity and composition in enset-coffee agroforestry home gardens of Southern Ethiopia. Journal of Agriculture and Rural Development in the Tropics and Subtropics, 114(2013), 29-38.

Arimi, K. (2014). Determinants of climate change adaptation strategies used by rice farmers in Southwestern, Nigeria. Journal of Agriculture and Rural Development in the Tropics and Subtropics, 115(2014), 91-99.

Armitage, D. R., Plummer, R., Berkes, F., Arthur, R. I., Charles, A. T., Davidson-Hunt, I. J., Wollenberg, E. K. (2008). Adaptive co-management for social-ecological complexity. Frontiers in Ecology and the Environment, 7(2), 95-102. doi: 10.1890/070089

Aune, J. B., \& Bationo, A. (2008). Agricultural intensification in the Sahel - The ladder approach. $\quad$ Agricultural Systems, $\quad 98(2), \quad 119-125 . \quad$ doi: http://dx.doi.org/10.1016/j.agsy.2008.05.002

Câmpeanu, C. N., \& Fazey, I. (2014). Adaptation and pathways of change and response: A case study from Eastern Europe. Global Environmental Change(0). doi: http://dx.doi.org/10.1016/j.gloenvcha.2014.04.010

CFU (2007). Conservation Farming and Conservation Agriculture: Handbook for Ox Farmers in Agro-Ecological Regions 1 and lla. Conservation Farming \& Conservation Agriculture. Lusaka, Zambia, Conservation Farming Unit.

Chamberlin, J., Sitko, N.J., Kutega, A., Lubungu, M., \& S. Tembo. . (2014). Maize Market Coordination in Zambia. An Analysis of the Incentives and Obstacles to Improved Vertical and Horizontal Marketing Arrangements Technical Report No. 2 Lusaka: Indaba Agricultural Policy Research Institute.

Chapoto, A., Haggblade, S., Hichaambwa, M., Kabwe, S., Longabaugh, S., Sitko, N., \& Tschirley, D. (2012). Agricultural Transformation in Zambia: Alternative Institutional Models for Accelerating Agricultural Productivity Growth and Commercialization IAPRI Working Paper No. 64. Lusaka: Indaba Agricultural Policy Research Institute (IAPRI).

Ellis, F. (1993). Peasant Economics. Cambridge: Cambridge University Press.

Ericksen, P. J., \& Ingram, J. S. I (2005). Global Environmental Change and Food Systems (GECAFS). IHDP Annual Report 2004-5. pp. 45-46.

FAO. (2011 ). Climatic Risk Analysis in Conservation Agriculture in Varied Biophysical and Socio-economic Settings of Southern Africa. Johannesburg: Regional Emergency Office for Southern Africa (REOSA). 
Farrington, J., \& Saasa, O. (2002 ). Drivers for Change in Zambian Agriculture Defining What Shapes the Policy Environment', report for DFID.

Gohari, A., Eslamian, S., Abedi-Koupaei, J., Massah Bavani, A., Wang, D., \& Madani, K. (2013). Climate change impacts on crop production in Iran's Zayandeh-Rud River Basin. Science of The Total Environment 442 (0), 405-419.

Govereh, J., Jayne, T. S., \& Chapoto, A. (2008). Assessment of alternative maize trade and market policy interventions in Zambia FSRP Working Paper No. 33. Lusaka: Food Security Research Project (FSRP).

GRZ. (2013). Ministry of Agriculture and Livestock: End of Year Report 2013. Choma: Department of Agriculture.

Haggblade, S., \& Tembo, G. (2003 ). Conservation Farming in Zambia. EPTD Discussion Paper No. 108. Washington. D.C., International Food Research Policy Research Institute.

Hamazakaza, P., Smale, M., \& H. Kasalu. . (2013). The Impact of Hybrid Maize on Smallholder Livelihoods in Zambia. Findings of a household Survey in Katete, Mkushi and Sinazongwe Districts Working paper 73. Lusaka: Indaba Agricultural Policy Research Institute.

Klein, J. T. R. (2003). Adaptation to Climate Variability and Change: What is Optimal and Appropriate? In E. E. C. Giupponi and M. Schechter (eds.) (Ed.), In: Climate Change in the Mediterranean: Socio-Economic Perspectives of Impacts, Vulnerability and Adaptation (pp. 32-50). Cheltenham, UK: Potsdam Institute for Climate Impact Research.

Langdridge, D. (2004). Introduction to research methods and data analysis in Psychology. England: Pearson Education Limited.

Mason, M. N., \& Myers, J. R (2011). The Effects of the Food Reserve Agency on Maize Market Prices in Zambia: Are There Threshold Nonlinearities. Working Paper No. 60. Lusaka, Zambia, Food Security Research Project (FSRP).

Mortimore, M. J., \& Adams, W. M. (2001). Farmer adaptation, change and 'crisis' in the Sahel. Global Environmental Change, 11(1), 49-57. doi: http://dx.doi.org/10.1016/S0959-3780(00)00044-3

Mubanga, K. H., \& Umar, B. B. (2014). Smallholder Farmers' Responses to Rainfall Variability and Soil Fertility Problems by the Use of Indigenous Knowledge in Chipepo, Southern Zambia. Journal of Agricultural Science 6(6), 75-85.

Saasa, O. S. (2003). Agricultural intensification in Zambia. The role of policies and policy processes. On the project: Africa Food Crisis-The relevance of Asian models, Institute of Economics and Social Research. University of Zambia. Collaborative study between Lund University and The Institute of Economic and Social Research, University of Zambia.

Sitko, N. J., Chapoto, A., Kabwe, S., Tembo, S., Hichaambwa, M., Lubinda, R., Chiwawa, H., Mataa, M., Heck, S., \& Nthani, D. (2011). Technical Compendium Descriptive Agricultural 
Statistics and Analysis for Zambia in Support of the USAID Mission's Feed the Future Strategic Review. LUSAKA, ZAMBIA, FOOD SECURITY RESEARCH PROJECT, WORKING PAPER No. 52.

Swift, J., \& Hamilton, K. (2001). Household food and livelihood security. In: Devereux, S., Maxwell, S. (Eds.), Food Security in Sub-Saharan Africa. ITDG, London.

Thomas, D. G., Twyman, C., Osbahr, H., \& Hewitson, B. (2007). Adaptation to climate change and variability: farmer responses to intra-seasonal precipitation trends in South Africa. Climatic Change, 83(3), 301-322. http://dx.doi:10.1007/s10584-006-9205-4.

Tembo, G., and Jayne, S. T. (2010). "Increasing Returns to Marketing in Zambian Maize Markets." Zambia Social Science Journal 1(2), 140-157.

Tembo, G., Kapekele, E., Tembo, A., Goma, F. Y., \& Sambo, J. (2014). Livestock trends and farmers' perceptions about their impacts in Southern Zambia. Journal of Agricultural Studies. 2(2), 11-20. http://dx.doi.org/10.5296/jas.v2i2.5397.

Umar, B. B. (2012). From Maize Mono-cropping to Conservation Agriculture: A Multi-perspective Analysis of Smallholder Conservation Agriculture in Southern, Central and Eastern Zambia. (PhD), Norwegian University of Life Sciences Norway.

Umar, B. B., \& Nyanga, P.H. (2011). Conservation agriculture and rainfall variability in Zambia: is CA a promising option for responding to droughts and floods? Paper presented at the 5th World Conference on Conservation Agriculture, Brisbane Australia.

Usman, M. T., \& Reason, C. J. C. (2004). Dry spell frequencies and their variability over southern Africa. Climate Research, 26(3), 199-211. http.//dx.doi: 10.3354/cr026199.

Vogel, C. (2000). Usable science: An assessment of long-term seasonal forecasts amongst farmers in rural areas of Sourth Africa. South African Geographical Journal, 82(2), 107-116. http://dx.doi.org/10.1080/03736245.2000.9713700.

Vogel, C. (2005). Seven Fat Years and Seven Lean Years"? Climate Change and Agriculture in Africa. IDS Bulletin 36(2), 30-35.

Zulu, B., Nijhoff, T. T., Jayne, T. S., \& Negassa, A. (2000). Is the Glass Half-Empty or Half Full? An Analysis of Agricultural Production Trends in Zambia. FSRP Working Paper No.3. Lusaka, Food Security Research Project.

\section{Copyright Disclaimer}

Copyright for this article is retained by the author(s), with first publication rights granted to the journal.

This is an open-access article distributed under the terms and conditions of the Creative Commons Attribution license (http://creativecommons.org/licenses/by/3.0/). 